\title{
Sławomir Redo
}

The United Nations Studies Association, Vienna

slawomir@redo.net

ORCID ID: https://orcid.org/0000-0003-2018-4217

\section{For more United Nations rule-of-law "win-win" technical assistance outcomes amid migration*}

\author{
http://dx.doi.org/10.12775.SIT.2021.035 \\ In memory of Professor Wiesław Daszkiewicz (1927-2013) \\ Director, Institute of Criminal Law and Law of Criminal Procedure, \\ Nicolaus Copernicus University, Toruń, Poland
}

\section{Introduction}

Saint Augustine (354-430), the bishop of Hippo Regius (now Anaba, an Algerian Mediterranean port), later one of the Doctors of the Church, reflects: "Remove justice, and what are kingdoms but gangs of criminals on a large scale? What are criminal gangs but petty kingdoms? A gang is a group of men under the command of a leader, bound by a compact of association, in which the plunder is divided according to an agreed convention. If this villainy wins

* The views in this article are solely of its author. They do not reflect the views of the ZUEL (Zhongnan University of Economic and Law/ZUEL, Wuhan, China). The text below builds on the author's online presentations at the Fourteenth United Nations Congress on Crime Prevention and Criminal Justice (Kyoto, Japan, 8 March 2021) and ZUEL's "Rule of Law Society - Changjiang International Forum 2021: Legal Response to Major Public Health Emergencies" (Wuhan, China, 19 June 2021). 
so many recruits from the ranks of the demoralized that it acquires territory, establishes a base, captures cities and subdues peoples, it then openly arrogates to itself the title of kingdom, which is conferred on it in the eyes of the world, not by the renouncing of aggression but by the attainment of impunity." ${ }^{1}$

Then he tells the story of a pirate captured seven centuries ago by Alexander the Great. He asked the pirate: "What is your idea, in infesting the sea?" And the pirate answered, with uninhibited insolence, "The same as yours, in infesting the earth! But because I do it with a tiny craft, I'm called a pirate; because you have a mighty navy, you're called an emperor."

The pirate's rejoinder and St. Augustine's reflection beg two questions relevant to the title of this article. First, what is "justice"; second, what to do for countering lawlessness cross-regionally, that is not only because of the disorderly migration in the Mediterranean region, but likewise inordinate elsewhere.

Regarding the first question, Augustine's immediate answer was that justice is "to render to every man his due". "Due" means: "all good things whatsoever ye would that men should do to you, do ye even so to them."3

In the $18^{\text {th }}$ century, the Quakers, religiously motivated progenitors of the United Nations anti-slavery policy, more explicitly stated: "There is a saying, that we shall do unto others as we would have them do unto us - making no difference in generation, descent, or color. What in the world would be worse to do to us, than to have men steal us away and sell us for slaves to strange countries, separating us from our wives and children? This is not doing to others as we would be done by; therefore we are against this slave traffic." 4

1 St. Augustine, Concerning the City of God against the Pagans, transl. H. Bettenson, London 1972, Book IV, 4.

2 Ibidem, Book XIX, 4.

${ }^{3}$ St. Augustine, Sermon on the Mount; Harmony of the Gospels; Homilies on the Gospels, in: P. Schaff, Nicene and Post-Nicene Father Series, Series I, Vol. 6 , Christian Classics Ethereal Library 2010, Book 2, XXII, p. 74.

4 Germantown Friends' protest against slavery 1688 [Facsimile], https:// bit.ly/3hePKmr (access: 15.07.2021). 
Regarding the contemporary world, it had to await the answers to the two questions until the establishment of the United Nations. Authoritative "Commentary on the United Nations Charter" explains that "justice [...] means something different from international law [...] and [...] refers to natural law." ${ }^{5}$ An intergovernmentally declared in the Global Compact for Safe, Orderly and Regular Migration Rule-of-Law definition says that "rule of law and due process and access to justice are fundamental to all aspects of migration governance. This means that the State, public and private institutions and entities, as well as persons themselves, are accountable to laws that are publicly promulgated, equally enforced and independently adjudicated, and are consistent with international law." ${ }^{6}$

Accordingly, under the UN aegis not justice per se, but access to it through numerous legal instruments (especially treaties) has gradually been advanced by regulating normatively how to counter various forms of crime, including piracy, other forms of organized crime and corruption. Since the late 1940s, the Organization's technical cooperation ${ }^{7}$ social welfare work has gradually matched its counter crime legal framework, ${ }^{8}$ but only since 1995 it has explicitly done so including the crime prevention component, starting at urban level. ${ }^{9}$

Since 2015, in the 2030 United Nations Sustainable Development Agenda, ${ }^{10}$ countering any crime has received relevant expression, inter alia, through its goal 10 "Reduce inequality within and

5 B. Simma (ed.), A. Paulus, E. Chatodou (ass. eds.), in collaboration with H. Mosler, A. Radelzhofer, Ch. Tomuschat, R. Wolfrum, The Charter of the United Nations. A Commentary, Oxford 2002, Vol. 1, p. 36.

${ }^{6}$ A/RES/73/195 §15 (d), The Global Compact for Safe, Orderly and Regular Migration, 19 December 2018.

7 Technical "cooperation" presumes non-humanitarian projects on a parity basis. Technical "assistance" is more often invoked, but may imply patriarchalism. "Developmental aid" implies socially just progressive technical assistance.

8 See further: S. Redo, Blue Criminology. The Power of the United Nations Ideas to Counter Crime Globally, Helsinki 2012, pp. 146-149, 194-197.

9 Ibidem, p. 97.

10 A/RES/70/1, General Assembly resolution 70/1, Transforming Our World: the 2030 Agenda for Sustainable Development, 25 September 2015. 
among countries" with its targets on the most economically vulnerable countries (10b) and countries whose migration policies do not meet the standard of orderly, safe, regular and responsible migration (10.7). In the Agenda's idealistic solidarity terms, fairness implies that donor states deal with weaker states as they would have stronger states deal with them. ${ }^{11}$ The United Nations wants both to do so with the "thick" definition of the Rule of Law. ${ }^{12}$

In this article sympathetic to realpolitik's understanding of solidarity I focus on a commensurate to SDG 10 concept: a difference principle proposed in 1971 by the US philosopher of law John Rawls (1921-2002). He interprets justice as a part of combination of liberty with equality of opportunity. The principle's reductionist premise accepts as fair diverging from strict equality so long as the inequalities in question would make the least advantaged in society materially better off than they would be under strict equality. ${ }^{13}$

Perhaps Rawls reflected on Tacitus' contention that: "men are readier to pay back injuries than benefits, since to require a benefit is felt to be a burthen, to return an injury a gain," cited by Machiavelli in his "History of Florence". ${ }^{14}$ Surely, though, it was Mitchell Sharp, Canadian Deputy Minister of Commerce and Trade (1951-1957), who should be credited for an effective scheme of technical cooperation. In 1961, he proposed it as follows: "If the primary purpose of our aid is to help ourselves, rather than to help others, we shall probably receive in return what we deserve, and a good deal less than we expect”. ${ }^{15}$

11 J.K. Rono, The Golden Rule as An Alternative Approach in the Fight Against Corruption, "Research on Humanities and Social Sciences" 2017, Vol. 7(16), p. 5.

12 For the difference between the "thick" and "thin" definitions of the Rule of Law, see. e.g. A. Bień-Kacała, T. Drinóczi, Rule of Law, Common Values, and Illiberal Constitutionalism Poland and Hungary within the European Union, London 2021, ch. 1.

13 J. Rawls, A Theory of Justice, Cambridge 1971.

14 N. Machiavelli, History of Florence, XXIX, 3, in: The Collected Works of Niccolò Machiavelli: The Complete Works, PergamonMedia 2015.

15 M. Sharp, Canada's Stake in International Programmes, "Dialogue" 1961, p. 47. 


\section{Universality of reciprocity}

Reciprocity is the backbone of all human sociality. It is recognized in customary law, philosophy and religion. In Africa's Ubuntu proverb "a human being is a human being through other human beings" resonates the Golden Rule/GR. ${ }^{16}$ If formulated negatively: "Do not impose on others what you do not wish for yourself", as originally in the Confucius' Analects ${ }^{17}$ then the rule prohibits harming others. However, if formulated positively as "Do Unto Others as You Would Have Them Do Unto You" (Matthew 7.12), ${ }^{18}$ then it recommends more action, eventually mutually satisfactory benefits/"win-win". ${ }^{19}$

Philosophers of law debated where to find the GR: in God or in the nature of men. Niccolò Machiavelli (1469-1527) answered: "It is the nature of men to be bound by the benefits they confer as much as by those they receive". ${ }^{20}$ Hugo Grotius (1583-1635), one of the founders of public international law, argued that it was a natural human inclination to have appetitus societatis - appetite for sociability to contribute to justice for peaceful coexistence with others. This should include abstaining from taking things from them. In case theft happens - punishing for it and repairing the damage. This rule can be deduced a priori, independently of its aposteriori occurrence in empirical positive law. ${ }^{21}$ Samuel Pufendorf

16 J.K. Rono, The Golden Rule, p. 4.

17 Confucius, The Analects of Confucius. A Philosophical Translation, transl. R.T. Ames, H. Rosemont Jr, New York 1998, Book 12.2 and 15.3.

18 For a more incisive interpretation see: N. Doxbury, Golden Rule Reasoning, Moral Judgment, and Law, "Notre Dame Law Review" 2009, Vol. 74, p. 1591 .

19 Since 2018 with BRI is seized the United Nations Human Rights Council where the term "mutually beneficial cooperation" is regarded as unclear hence replaced in the Council's resolutions by "win-win cooperation". See: A/ HRC/43/31, The Role of Technical Assistance and Capacity-building in Fostering Mutually Beneficial Cooperation in Promoting and Protecting Human Rights, 17 January 2020, §§ 37-48.

20 N. Machiavelli, The Prince, X, in: The Collected Works.

${ }^{21}$ H. van Eikema Hommes, Grotius on Natural and International Law, “Netherlands International Law Review” 1983, Vol. 30, No. 1, p. 68. 
(1632-1694), another co-founder, saw the GR as implanted into our reason by God. ${ }^{22}$ In any case, this relational principle of natural law of mutual regard acknowledges the Other, and exerts a latent compulsion to reciprocate. ${ }^{23}$ However, critical to this article is not this answer, but reply to the question regarding the commensurability of mutual benefits in technical cooperation terms, i.e.: "We would wish for more than our share, if we had our own way; so do we also owe to others more than their share?", asked by Gottfried Leibniz (1646-1716). ${ }^{24}$

What we know so far is that one or another reciprocal effect can only be assessed intuitively - to the point of acknowledging that the GR is of "inestimable value". ${ }^{25}$ This text ventures into the more fitting value of mutual benefits from technical cooperation for the Rule of Law, especially through sustainable development goal 10.

I do so mindful of:

- The working definition of technical cooperation to be understood as "what a State is able to provide to another State (or States) in order to obtain some benefit for both parties in the field of human rights, such as mutual understanding, equality and respect, or the healthy development of global human rights governance with the participation of developing countries" ${ }^{26}$, and

22 S. Pufendorf, On the Law of Nature and Nations, $4^{\text {th }}$ ed., London 1729 , Book 2, 3:13, pp. 134-135.

23 J.K. Rono, The Golden Rule, p. 4; H. Roetz, Transfer in Dispute: The Case of China, in: Cultural Transfers in Dispute Representations in Asia, Europe and the Arab World since the Middle Ages, eds. J. Feuchter, F. Hoffmann, B. Yun, Frankfurt-New York 2011, pp. 279-280.

24 G.W. Leibnitz, New Essays on Human Understanding, eds. and transl. P. Remnant and J. Bennet, Cambridge 1997, Book 1, § 4, 91.

25 M. Singer, "Golden Rule”, in: Encyclopedia of Philosophy, ed. D.M. Borchert, $2^{\text {nd }}$ ed., Detroit, MI 2006, p. 144, https://www.encyclopedia.com/ philosophy-and-religion/christianity/christianity-general/golden-rule (access: 15.07.2021).

${ }^{26} \mathrm{~A} / \mathrm{HRC} / 43 / 31, \S 33$. 
- The emblematic to the United Nations rule "Do Unto Others as You Would Have Them Do Unto You". ${ }^{27}$

The above rule constitutes the Organization's own ecumenical message, based on the golden rule-like recite from the Universal Declaration of Human Rights: "All human beings are born free and equal in dignity and rights. They are endowed with reason and conscience and should act towards one another in a spirit of brotherhood." ${ }^{28}$ It epitomizes all like-minded expressions in custom, religions, legal philosophies and cultures. No doubt, in this regard the United Nations has a unique global position. It may revive, orchestrate scientifically and operationalize the rule's reciprocal value through technical assistance.

\section{Social justice and fairness in different legal cultures}

In the pre-SDGs era, cultural anthropologists were looking at the question where the essence of normativity actually resides. For this purpose, they employed various game theory bargaining and cooperation experiments. They involved 792 pairs and triads of players from various populations from five continents, altogether 1762 anonymous adults from 15 diverse groups ranging from tribes through urban residents (wage earners) to college students.

The results suggest that:

- Each group had its own way of reacting to financially costly punishment;

27 H. Kury, S. Redo, Prologue, in: Crime Prevention and Justice in 2030. UN and the Universal Declaration of Human Rights. Essays in Honour of the United Nations, eds. H. Kury, S. Redo, Cham 2021, p. 716.

28 Universal Declaration of Human Rights, General Assembly resolution 2017 (III A), 10 December 1948. For the etymology of this formulation, see, e.g., Y.-J. Zhang, The Universal Declaration of Human Rights: Public International Law and the Confucian Legal Culture for 2030 and Beyond, in: Crime Prevention, pp. 603-622. 
- In every group less-equal offers were financially punished more frequently, with some groups which punished for offers that were either too generous or too stingy. ${ }^{29}$

General conclusions from various experimental games are:

- The same social justice patterns may function quite differently in different groups across the world, and with greater variance than among urban college-level students ${ }^{30}$;

- The conduct of these groups documents their own cultural equilibria and commensurate fair distribution of benefits;

- This variation in the levels of access justice and in fairness should be explained by different group learning dynamics and outcomes;

- Under plausible conditions (individually attractive objective/ incentives/pay-offs) some of such outcomes will be positive, provided that there is civil society vigilance/community monitoring prompting good governance sanctioned by free and fair electoral vote, with cost efficient control of corruption and effective system of fines for breaching the rules of coexistence $^{31}$;

- Depending on the openness, size and composition of the group rather than a disposition of a single individual, they enable the adoption of new standard of conduct within one generation (15-30 years) and its spreading to neighbouring groups thus prompting the multiplier effect ${ }^{32}$ );

- While such an effect emerges slowly, it depends on advancing a new standard of conduct as a majority's preference through communicating first the conduct's most appealing

29 J. Henrich et al., Costly Punishment Across. Human Societies, "Science" 2006,Vol. 312, pp. 1767-1770.

30 Ibidem, p. 1768.

31 E. Acinelli et al., Who controls the controller? A dynamical model of corruption, "The Journal of Mathematical Sociology" 2017, Vol. 41, No. 4, pp. 220-247, https://doi.org/10.1080/0022250X.2017.1388235 (access: 15.07.2021).

32 R. Boyd, P. Richerson, Group Beneficial Norms Can Spread Rapidly in a Structured Population, "Journal of Theoretical Biology" 2002, Vol. 215(3), p. 287. 
and agreeable common element by a "moral entrepreneur" or

"significant other", in any case a prestigious public leader. ${ }^{33}$

Finally, since customary justice may make up to $80 \%$ of the dispute settlements in post-conflict countries, to fully understand how the Rule of Law can be promoted through technical assistance projects, it is necessary to measure by benchmarks the impact of customary mechanisms upon it, however vague they occasionally are. ${ }^{34}$

The results of the game theory experiments would have been different now, because of the recency of migration. ${ }^{35}$ The residency cultural values of immigrants can affect the cohesion of cultural values within any group (experimental or not). In post-conflict societies such a result will certainly be quite adverse. One or another factor (or both) should then be credited for place-to-place divergences in the Rule-of-Law technical cooperation outcomes.

For identifying the essence of such cultural equilibria with commensurate Rule-of-Law developmental potential only one very elementary question must be solved: if a provider and recipient of technical assistance share, and then to what extent, one root social value initially common within two respective groups involved in technical cooperation. And this is the GR of reciprocity (mutual benefits/"win-win") - the "fair" part of "justice."

33 Cf. J. Henrich, R. Boyd, Why People Punish Defectors: Weak Conformist Transmission can Stabilize Costly Enforcement of Norms in Cooperative Dilemmas, "Journal of Theoretical Biology" 2001, Vol. 208(1), pp. 79-89.

34 B. Baker, E. Scheye, Access to Justice in a Post-conflict State: Donor-supported Multidimensional Peacekeeping in Southern Sudan, "International Peacekeeping" 2009, Vol. 16(2), pp. 171-185.

${ }^{35}$ H. Kury, S. Redo (eds.), Refugees and Migrants in Law and Policy - Challenges and Opportunities for Global Civic Education, Cham 2018. The book comprises 35 relevant texts of 48 authors. It points to the inevitability of migration and to the ways and means of domesticating its impact for social justice. 
324 Stawomir Redo

\section{The United Nations' quest for justice as fairness in technical cooperation}

At the same time when academics laboured over the rules involving incrementally viable to local groups social justice outcomes, in 2000 the United Nations in its Millennium Goals Declaration has started working towards a fair globalization by addressing a major moral indictment: extreme poverty. Then - for the first time ever the General Assembly formulated the solidarity principle: "Those who suffer or who benefit least deserve help from those who benefit most". ${ }^{36}$ In 2015 in the Sustainable Development Agenda this solidarity principle has been crystallized into a slogan of "leaving no one behind" by 2030.

Since 2000, the UN has set one clear benchmark for those who benefit least, i.e. absolutely materially deprived: eliminating worldwide extreme poverty measured as a proportion of people living on international \$ 1.90 a day. ${ }^{37}$ The extreme poverty dropped since 1820 from 94\% (the first year in which that rate was set), in 1945 to $75 \%$ and in 2015 to $10 \% .^{38}$ So interpreted poverty can be reduced to $6 \%$ in 2030 and eventually eliminated later.

Surely, although "poverty is the parent of revolution and crime"39 (Aristotle), yet neither crime nor its prevention will disappear with the elimination of absolute material deprivation. When inequality is weak and so is tax enforcement practice, corruption may continue. ${ }^{40}$ Corruption has a self-enforcing nature, and other crime has

36 A/RES/55/2, The Millennium Goals Declaration, 18 September 2000, $\S 6$.

37 Extreme Poverty - Data Documentation, https://bit.ly/2UsGUZt (access: 15.07.2021).

38 M. Roser, E. Ortiz-Ospina, Global Extreme Poverty, https://bit.ly/3jZOPcS (access: 15.07.2021).

39 Aristotle, Politics, Book II, ch. 6, p. 1156 at 1265, 11-12, in: The Basic Works of Aristotle, ed. R. McKeon, New York 2001.

40 R. Cerqueti, R. Coppier, A Game Theoretical Analysis of the Impact of Income Inequality and Ethnic Diversity on Fiscal Corruption, "Annals of Operations Research" 2016, No. 243, pp. 71-87, doi 10.1007/s10479-014-1567-9. 
its own aetiology beyond poverty. Stakeholders of crime prevention and criminal justice need developing a technical assistance approach that accounts for these facts.

This is signalled through Mitchell Sharp's practical experience, John Rawls's difference principle - incidentally both relevant to the goals of the 2030 United Nations Sustainable Development Agenda. These goals constitute what the GR researchers call for, namely and somewhat euphemistically, "a domain of attraction of the group beneficial strategy". ${ }^{41}$ In other words, specifically and locally aiming at, e.g., "anti-corruption" (SDG 16.5), "homicide reduction" (SDG 16.1) "anti-discrimination" (SDG 16.10a), or "access to justice" and "the Rule of Law" (SDG 16.3), excessive inequality within a country and among countries in general (SDG 10) exactly is that domain of attraction for technical assistance providers and recipients.

The review of 1950s-2010s strategic goals of Western technical assistance shows that since the 2000s it has focused on a more effective public sector that "owns" development, so to ensure effective aid. ${ }^{42}$ In the 2010 s technical assistance resurfaced in a strategy of "Western powers... [to-added] make sure that growing countries will make the right choices after 'graduating' from Western aid". Finally, the reviewers asked: "Will we be able to keep momentum after 2015?"43

At about the same time at the joint session of the United States Congress, Pope Francis called on this major aid donor: "Let us seek for others the same possibilities which we seek for ourselves. Let us help others to grow, as we would like to be helped ourselves. In a word, if we want security, let us give security. If we want life, let us give life. If we want opportunities, let us provide opportunities.

41 R. Boyd, P. Richerson, Group Beneficial Norms, p. 288.

42 In more radical review their authors criticised it as racialized imperial form to promote "the Rule of Law" around the world, with the United Nations as its partaker (see S. Chalmers, The Mythology of International Rule-Of-Law Promotion, "Law and Social Inquiry" 2012, Vol. 44(4), p. 958).

43 E. Oyvind, R. Kjell, Western Aid at a Crossroads. Western Aid at a Crossroads: The End of Paternalism, London 2014, p. 20. 
The yardstick we use for others will be the yardstick which time will use for us." ${ }^{44}$

\section{Operationalizing the difference principle for the Rule-of-Law technical assistance}

Mitchell Sharp's credo may be an ideological foundation for development that is not self-serving, moralistic but moral. Save Nordic countries and Australia, other Western donor countries are criticized because of their past colonizing exploitative and patronizing practices. India, China, the Republic of Korea or Turkey and the UN are less prone to charges of unfair practices and ensuing requests from their clients for compensation. This should prompt to think whether some ideologies, laws and policies addressing the Rule of Law may thwart or facilitate the progressive agenda of the United Nations - "a benevolent conqueror" 45 , to update Montesquieu's concept to support socio-economic development for 2030 and beyond.

The UN moral mandate is relatively strong. Even if not so strong as before 2003 (i.e. when the Security Council's authorized the military intervention in Iraq), the UN still has moral prestige and pursues intercultural logics for ecumenical purpose, especially well communicated through the 2030 Agenda. The UN with its own aid allocation pattern reasonably fixed on human development goals well interplays with other donor/recipient countries' priorities as far as their human security is concerned.

44 Congressional Record. United States of America. Proceedings and Debates of the 114 $4^{\text {th }}$ Congress, First Session, Vol. 161, Washington, September 24, 2015, No. 138, https://bit.ly/3yhFgIG (access: 15.07.2021).

$45 \mathrm{Ch}$. Volk, The Law of the Nations and the Civil Law of the World. On Montesquieu's political Cosmopolitanism, in: Order, and International Law System. The Early History of International Legal Thought from Machiavelli to Hegel, eds. S. Kadelbach, T. Kleinlein, D. Roth-Isigkeit, Oxford 2017, p. 242. 


\section{Equivalence of benefits}

Ideally, technical cooperation should be equally beneficial to the involved countries and their constituencies in terms of their own development. But "[t]here is no independent account of what it is for a will to be just" ${ }^{46}$ In practice, mutual benefits may be inequitable but only insofar this works to the parties' reasonable advantage. How to identify and apply the functional equivalents of such mutually reasonable outcomes is a difficult matter, especially where the Rule of Law may be absent or has minimal legitimacy for the population ("thin" definition). Had this inequivalence only been the perennial problem of technical assistance, then one could look for solutions in the theory. But also there it is perennial.

In "Analects", Chinese culture scripture, Confucius says that reciprocity with respect to benefits is perpetually relative. ${ }^{47}$ From him comes the idea of scaling/weighing (quan), ${ }^{48}$ that is of making decisions under specific circumstances where standard prescriptions of behavior would fail to meet the requirements of the situation. ${ }^{49}$ Situationally, the failures of technical cooperation can be reduced, if not rectified, by aiming locally in the specific developmental projects at mutually fair and just outcomes.

But Confucius shows no pattern for fair and equal distribution of benefits. He approaches justice enigmatically. While its distributive aim is to provide necessary material conditions to its members for their moral excellence, Confucianism generally does not look at moral excellence of individuals but seeks to create a society, where

46 G.W. Leibnitz, New Essays, Book I, § 4, 92; idem, New Essays on Human Understanding, transl. and ed. J. Bennett, Book I, § 4, p. 28, https://bit. ly/3AvsZSL (access: 15.07.2021).

47 Confucius, Analects, Book 15.4; M.M. Dawson, The Ethics of Confucius. The Sayings of the Master and his Disciples upon the Conduct of "The Superior Man", Arranged According to the Plan of Confucius with Running Commentary, New York 1915, p. i.

48 Confucius, Analects, Book 9.30; A.C. Yu, Comparative Journeys: Essays on Literature and Religion East and West, New York 2009, p. 353.

49 H. Roetz, Transfer in Dispute, p. 269. 
necessary material conditions are provided for it to its members. Consequently, "different statuses can exist in a society not because people are different by nature but because they become different through their effort to develop their virtue, knowledge, and skills... The main goal of Confucian corrective justice is to support and restore harmony and peace in human relations, not to maintain the legal order [emphasis added], to punish violators, and to protect individual rights by upholding a basic social contract or positive laws (laws explicitly stated and promulgated by a political authority)." 50

Aristotle who wondered how many shoes are equal to a house (or for a given amount of food) so as to the ratio of builder to shoemaker, observed that reciprocity is very inexact when it comes to benefits and very exact when it comes to evils. ${ }^{51}$ As a result of this thought exercise, he argued that justice ensues from the awareness of proportion in human relationships, a proportion which reflects the degrees of merit in each party. A variety of things may constitute merit. Not their particulars but their general balance determine just response. "[F]or all men agree that what is just in distribution must be according to merit in some sense, though they do not all specify the same sort of merit, but democrats identify it with the status of freeman, supporters of oligarchy with wealth (or with noble birth), and supporters of aristocracy with excellence". ${ }^{52}$ Even as this sounds less enigmatically than Confucius' idea of equivalent benefits, eventually what is just or unjust can be best replied under the universal law of nature - "an all-embracing law, through the realms of the sky/Unbroken it stretcheth, and over the earth's immensity" ${ }^{3}$, hence potentially commensurable with Western and Eastern legal culture.

50 B. Seok, Justice and Religion: Confucianism, in: Encyclopedia of Global Justice, 2011, https://doi.org/10.1007/978-1-4020-9160-5_145 (access: 15.07.2021).

51 Aristotle, Nichomachean Ethics, Book 5, sec. 5, 1133-1134.

52 Ibidem, Book 5, sec. 3, 1131.

53 Aristotle, Rhetoric, Book I, ch. 12, 1373. 
Finally, Charles Montesquieu, one of the intellectual precursors of the UN technical assistance, felt that in primitive societies justice is a mixture of patriotism and mutual consideration. The latter principle is invariable. But in modern societies where justice is a sophisticated concept, mutual consideration not only involves the idea of relationship with its structural and cognitive associations, but also the overarching idea of justice. It is set out by a transcendent authority as "the proper relationship that exists between two things. This relation is always the same, no matter what creature is viewing it, whether God, an angel, or a man. ${ }^{54}$ In this disquietedly vague pronouncement of a practicing magistrate, he credits the essence of this implicitly two-side congruence to whoever considers it. Accordingly, this relationship is either descriptive or normative. It respectively depends on naturalistic/spiritual or positivistic approach to "things". ${ }^{55}$ Here he stops and invites his readers to calculate the degrees of liberty to enjoy with moderate governance, if to pursue his idea of the distribution of the three powers. His business is not to make people read, but to make them think. ${ }^{56}$

This text follows the latter approach, but with due recognition of invariable law of reciprocity ("mutual regard") - the (non)secular "thing". Save it - which indeed stretches over the earth immensity the other "things" are speculative.

Justice is like a black box. Technical assistance providers know it. What they may not appreciate is the imminent shift in the order of "things", i.e. that the Rule of Law "win-win" outcomes may be challenged by climate change and migration and reprioritized for sustainable development that hopefully restores harmony and peace in human relations. Their business should be to make the Rule of Law work amid changing values. It is a matter of time. It is a matter of the 2030 UN Sustainable Development Goals Agenda

${ }^{54}$ Ch. Montesquieu, Persian Letters, transl. R.N. Mackenzie, Indianapolis/ Cambridge 2014, LXXXIV, p. 124.

55 Ibidem.

56 Ch. Montesquieu, The Spirit of Laws, transl. T. Nugent, Kitchener 2001, Book XI, 20, p. 201. 
with the Organization's intercultural logics and Reason to implement it until then and as reconstituted later. ${ }^{57}$

As of this writing, in "win-win" technical assistance the UN mostly expresses its reason through the resolutions of its Human Rights Council, primarily negotiated between USA and China with respective support of other Member States. The debates over draft resolutions show incongruency in approaching that assistance conceptually, motivated by the rival project-based priorities and deliverables and respective worldviews. ${ }^{58}$

\section{The difference principle and the UN logic of equivalence of benefits}

What measure or volume of benefits makes a donor and a recipient really satisfied, assuming that such a satisfaction is commensurate with the level of cultural and socio-economic development of cooperating countries? In search for this answer, I will now apply John Rawls's difference principle to the UN Rule-of-Law driven technical assistance, and reinterpret technical assistance in the context of migration.

The restated ${ }^{59}$ difference principle in the UN reference terms fully reads as follows:

Suppose that $\mathrm{x}_{1}$ is the a donor country with a high ranking in the Human Development Index of the United Nations Development Programme (UNDP). As its expectations are increased so are the prospects of a recipient country $\left(\mathrm{x}_{2}\right)$ - the least developed with a low score in the UNDP Human Development Index. In the Figure 1 the curve OP [Original Position] represents the contribution to

57 S. Redo, The Relevance of Philosophical and Religious Ideas to the United Nations Quest for Universalizing Criminal Justice, in: Crime Prevention and Justice in 2030. UN and the Universal Declaration of Human Rights, eds. H. Kury, S. Redo, Cham 2021, pp. 575-602.

58 A/HRC/43/31, The Role of Technical Assistance and Capacity-building in Fostering Mutually Beneficial Cooperation in Promoting and Protecting Human Rights, 17 January 2020.

59 The original text is in J. Rawls, A Theory of Justice, p. 76. 


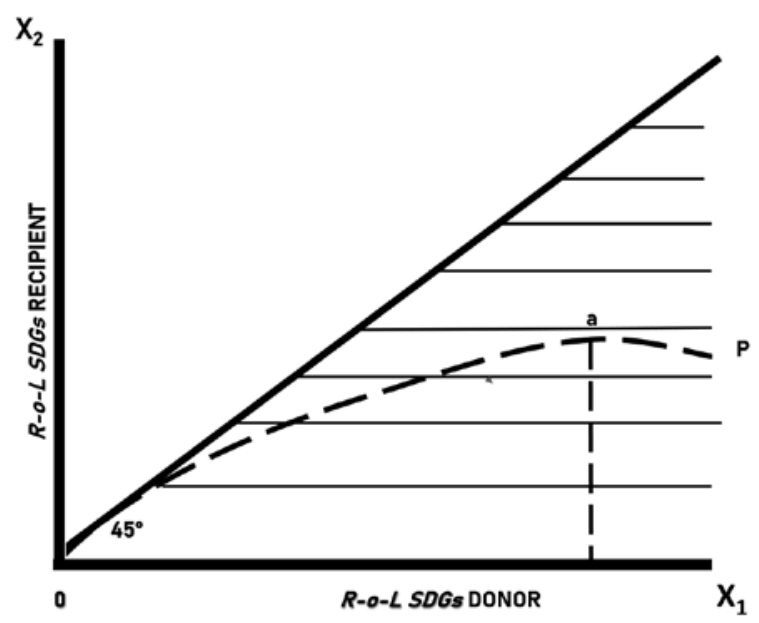

Figure 1. The difference principle as a principle of justice for the United Nations Rule-of-Law SDGs technical assistance

Figure 1. Mutual benefits may be inequitable but only insofar this works to everyone's reasonable advantage to the point that these benefits should be fair in terms of an agreed and expected cooperative outcome, whose delivery is measured by "a suitable benchmark of comparison" (J. Rawls, Justice as Fairness, p. 262). In the SDGs technical assistance field regarding migration, the benchmarks of comparison for deliverables include numerous quantitative and qualitative targets across the social, economic, and environmental dimensions of sustainable development. These various deliverables should result from the broadening of the accountability to laws that are publicly promulgated, equally enforced and independently adjudicated, and are consistent with international law.

Source: Adapted from J. Rawls, A Theory of Justice, p. 76.

recipient country's expectation $\left(\mathrm{x}_{2}\right)$ made by the greater expectations of a donor country. The point $\mathrm{O}$, the origin, represents the hypothetical state in which all social primary goods are distributed equally. Now the Original Position is always below the $45^{\circ}$ line, since a donor country is always better off. Thus, the only relevant parts of the indifference curves are those below this line, and for this reason the upper left-hand part of that figure is not drawn in. Clearly the difference principle is perfectly satisfied only when the Original Position curve is just tangent to the highest in-difference 
curve it touches. In this Figure 1 it is at the point a. Past it no matter how much either party's situation is improved, there is no gain from the standpoint of the indifference principle unless the other gains too (Figure 1).

The identification of such mutually fair and just gains is contingent on researching and identifying the respective "cultural equilibria" with inner developmental potential of donor and recipient constituencies. This identification may help to mutually reinforce aspirations to pursue commensurate access to justice in accordance with the Rule of Law. Adverse drivers of migration, like insecurity, institutional and "street" corruption alert to a multipronged longterm approach for private-public partnerships for the next 15-30 years, in any case as long as development aid strategies may foresee.

Accordingly, it would be good to hear answers from policy-makers and developmental aid specialists to the questions like:

- Should a construction of a sport stadium by a donor give satisfaction only to central government officials of a recipient country, or whether that satisfaction should also extend to the contracted local entrepreneurs, or - maybe - it should extend further to a youth group in conflict with the law which now can spend on that stadium their hours under a coach's eye; to school with an intercultural curricula; to fund citizen participatory budget?;

- Should a construction of a water dam entail only the investment in the infrastructure or also in assisting in sorting out local ownership and land-use questions for staying put and sustainable livelihood?;

- Are there viable and impartial dispute/conflict resolution mechanisms in place?

- Are donors and recipients in concert regarding effective civil society anti-corruption vigilance/community monitoring?

- How relevant to the R-o-L outcomes would be providing school bags rather than civic and sexual education?;

- What integrity measures which control for greed and stinginess can be pursued through (in)formal education?

- How participatory R-o-L outcomes can be inculcated in foreign language courses? 
- What about donor's returns from a project? (future raw material contacts?, privileged trade rights?; sister city follow-up projects?).

If my memory serves me well, the United Nations Office on Drugs and Crime - the caretaker of the Education for Justice Programme - offers guidance in its various primary, secondary and tertiary education modules about tolerance and integrity (and integrity is implicitly about honoring agreements and respecting others), but there is no explicit guidance how to negotiate functionally equivalent reciprocity, that is "mutual benefits". Is it a guessing game? Trial and error?

\section{Point $a$ at the Original Position curve and Artificial Intelligence}

No longer. In the opinion of Alistair Duff Artificial Intelligence/AI can regulate social and economic institutions as any other inequality "so that differentials demonstrably work for the good of all, and especially the worst off." 60 "Unlike humans" - we read in another opinion - "AI can potentially reduce pre-assumptions and biases by analyzing given data inputs with algorithms. In comparison, AI can lessen human emotions and prejudices that can develop from past experiences, allowing the computer to make the most objective business decision." 61

It seems that so also feel many donors. For instance, China and UNICEF employed Artificial Intelligence to address their aid projects. ${ }^{62}$ The remaining question is whether indeed academics, policy makers and field-level specialists could so orchestrate "point a" for a local developmental aid project, so it will respond to a cul-

60 A.S. Duff, Neo-Rawlsian Co-ordinates: Notes on A Theory of Justice for the Information Age, "International Review of Information Ethics" 2006, Vol. 6(12), p. 21.

61 R. Cholwerinski, Can Artificial Intelligence Lessen Biases and Create $a$ "Veil" in Businesses?, 2018, https://bit.ly/3qMHg96 (access: 15.07.2021).

62 E.g. J. Hatch, 6 Ways Artificial Intelligence is Being Used in International Development, 8 August 2019, https://bit.ly/3fF5BbO (access: 15.07.2021). 
334 Stawomir Redo

tural equilibrium most viable for the Rule-of-Law crime prevention outcomes, and nobody will be left behind.

This could look like a happy end, but...

\section{Is it a happy story?}

Even if Tacitus draws credit for his intuitive assessment of GR it was cultural anthropologist Robert Boyd who after the experimental research of cultural equilibria discussed above said: "All that increased cooperation has done is change the scale on which conflict takes place [emphasis added]... I would like to think there's a happy story of peace and understanding. But you can't be a $21^{\text {st }}$ century human and not see that the trend is in the other direction". ${ }^{63}$

For a happy story then, educationists, educators and technical assistance stakeholders should be alerted to deal "cradle-to-grave" with prejudice, discrimination and hatred through participatory programmes, projects and curricula which inculcate into partakers' minds reciprocity (fairness to others as to oneself) as the basis for mutual understanding and cooperation.

Mutual regard is a canonical value. No matter whether in countries with Ubuntu culture, Buddhism, Confucianism, Judeo-Christianity, Islam or laïcité. It presupposes in every country a society has not reduced to law \& order and bread-and-butter solutions, but to Rule-of-Law positive outcomes. In the SDGs era, the Rule of Law should be a precursor to sustainable peace and justice through intercultural logics of local ownership of technical assistance projects with viable in-kind outcomes. A log frame matrix must account for this GR variable and outcome.

63 Guoted in: G. Vogel, The Evolution of the Golden Rule, "Science" 2004, Issue 303, p. 1130, doi: 10.1126/science.303.5661.1128. 


\section{Crime prevention is a social resource}

Crime prevention is a social resource. That is the place where Rule-of-Law outcomes can emerge. The energies for crime countering may come through the cooperation schemes without which everyone's well-being is at many risks through delinquency, offending and victimization. In "win-win" R-o-L crime prevention contribution in a recipient country depends essentially on the local cultural equilibrium combining economic opportunities and social conditions, not from isomorphic mimicry. In particular, how various citizens' rights and duties make crime prevention work to leave no one behind. This "solidarity principle" or "principle of difference" is less difficult to operationalize through the UN sustainable development goals. It entails local ownership of projects with various grass roots level investments aiming at returns documenting social energies and Rule-of-Law outcomes of local communities. Anti-corruption sentiments are crucial and so is the responsiveness of policy-makers to them.

The above factors point to reasonableness of a technical assistance project. Whether now or after 2030, State (central authorities), local authorities, community and religious leaders, various risk and vulnerable groups, including corrupted or otherwise criminally victimized, are together in a position to take the counter crime challenge in their hands, have the ownership of a project and account for its outcome. They are the original "producers" of safety, of the Rule of Law. They demonstrate this through their daily experiences and postulates. Conditional expectations of a donor, that is returns for investments made into crime prevention, may only be met if a recipient country follows suit, e.g. demonstrates RoL - driven safety outcomes/crime reduction/better access to justice - whatever target/indicator/benchmark is relevant for the project within many benchmarks developed for the evaluation of the 2030 UN Sustainable Development Agenda.

In the light of the above, GR which is the heritage of almost any culture has a great reconciliation and restoration potential. It is 
a routine principle of action, yet overlooked in the Blue Dot Network (BDN)/Build Back Better World (B3W).

Comparing justice to a black box reminds of a plane's flight recorder facilitating the investigation of aviation accidents and incidents with a view to preventing their recurrence. Also metaphorically, evaluation of technical assistance projects should be done "back to the future". However, "[o]ur task is not to foresee it, but rather to enable it to happen" ${ }^{64}$ Certainly, John Rawls's insightful difference principle is helpful for approaching the future so there will be more Rule-of-Law successful outcomes, even though it may only be a part of "the magic" of crime prevention.

Philosophical insights of others, let alone of Confucius, are likewise helpful. The full sense of his GR as a positive injunction and relative advantage through technical assistance may well be appreciated through the answer to his student. He asked him how to document his ren (benevolence/perfect virtue). ${ }^{65}$

Concerning the positive injunction, Confucius replied: "When you go abroad, behave to every one as if you were receiving a great guest; to employ the people as if you were assisting at a great sacrifice; not to do to others as you would not wish done to yourself; to have no murmuring against you in the country, and none in the family". Concerning the relative advantage, the student reacted: "Though I am deficient in intelligence and vigour, I will make it my business to practise this lesson." 66

Since "Those who know virtue are few"67, then the lesson for others is: practicing that business is about perpetually relative "mutually beneficial cooperation". Artificial Intelligence may be helpful to make it less ambiguous. Human intelligence should make cooperation work for peace and justice in the world - so much at stake in the era of migration and competing for minds and hearts of Global North-South development initiatives.

64 A. de Saint-Exupéry, The Wisdom of the Sands, in: La Citadel, transl. S. Gilbert, New York 1948, p. 51.

65 Also translated as charity, altruism, humanity, goodness.

66 Confucius, Analects, Book 12. 2, transl. J. Legge, pp. 115-116.

67 Ibidem, Book 15. 3, p. 222. 


\section{1. "Next fifty years"}

In 1320, Dante Alighieri in his "Divine Comedy" warned about forecasting. For him Hell (Inferno) is reserved for those who presume to peer too far into the future. Their punishment, for all eternity, is to have their heads permanently reversed to the back. ${ }^{68}$

That could have been only a temporary imposition on Jonathan Edwards, Pastor of a church in New-Haven (CN, USA). In 1791, when he preached regard to justice and dignity for slaves, he envisioned branding slavery "as shameful [...] as [...] robbery or theft", and its abolition "in the next fifty years". ${ }^{69}$ Slavery was abolished in the USA in 1865 - seven decades later. He must have then been reprieved.

In 2012, the OECD Secretary-General commenting on the shifting balance of economic power along the North-South axis over next fifty years concluded that: "The world our children and grandchildren inherit may be starkly different from ours". ${ }^{70} \mathrm{He}$ referred to the rising economic power of China, India among other developing countries which will entail a new hegemonic logic in the world.

Notwithstanding Dante Alighieri's warning, still two other facts may be important for technical assistance in the next fifty years if not longer. First, moral conduct first of all depends on survival, as Mencius (372-289 BCE) said..$^{71}$ Therefore, poverty alleviation through technical assistance will remain important, but likewise important will be the ratio with which donors will address survival

68 D. Alighieri, The Divine Comedy, transl., ed. and introduced by R. Kirkpatrick, London 2012, Canto XX, 13 \& 37.

69 J. Edwards, The Injustice and Impolicy of the Slave Trade and of the Slavery of Africans. A Sermon, New Haven, CN 1791, p. 30, https://bit. ly/2THRSKE (access: 15.07.2021).

${ }^{70}$ Balance of economic power will shift dramatically over the next 50 years, says OECD, 09/11/2012, https://bit.ly/3hG00mx (access: 15.07.2021).

${ }^{71}$ X. Jiang, Mencius on Moral Responsibility, in: The Examined Life: Chinese Perspectives: Essays on Chinese Ethical Traditions. Global Publications, Binghamton University 2002, pp. 146-147. 
values vs. emancipative values. The results of the sixth wave of the World Values Survey (WVS) 2014-2017 ${ }^{72}$ suggest in emerging powers "survival values", i.e. priority of security over liberty, non-acceptance of homosexuality, abstinence from political action, distrust in outsiders (i.e. the Others) and a weak sense of happiness prevail over "post-material" self-expression/emancipative values (freedom of thought). The latter are characteristic of the North countries, especially those to which today the Others, i.e. refugees and migrants, flock. Since social attitudes towards social diversity and others and public's political participation are more conservative in emerging powers in comparison with present powers, with growing migration in future there may be a lesser tolerance of emancipative values, at least on the Western terms. ${ }^{73}$

Second, as the world population is aging, we become less tolerant, less liberal or more conservative. ${ }^{74}$ Aging; migration, climate change; technology information developments, including Artificial Intelligence, but also cybercrime and digital surveillance call into question the emancipative ethics of "larger freedom" and the universality of moral principles, of "conscience of humankind" and brotherhood, respectively declared in the United Nations Charter and the Universal Declaration of Human Rights.

"Survival" values prompt identity crises in societies undergoing change in their ethnic make-up, documented by xenophobia and hate crime. Such manifestations counter the spirit and letter of the 2030 Agenda. No doubt, the pandemic dramatically highlighted xenophobia because of the debated origin of COVID-19 virus. The pandemic also exacerbated inequalities among countries (SDG 10) to the point, that "the world is on the brink of a catastrophic moral failure - and the price of this failure will be paid with lives and livelihoods in the world's poorest countries". ${ }^{75}$ There may be a further dissection of social justice values. The (non)

72 Inglehart-Welzel Cultural Map, https://bit.ly/3qSKNTE (access: 15.07.2021).

${ }^{73}$ H. Kury, S. Redo, Epilogue, p. 902.

74 Cf. H. Kury, S. Redo (eds.), Refugees and Migrants, pp. xxxii-xxxiii; 902.

75 WHO Director-General's opening remarks at $148^{\text {th }}$ session of the Executive Board, 18 January 2021, https://bit.ly/3jNCVkM (access: 15.07.2021). 
humanitarian international initiative B3W underpinning the BDN for meeting the infrastructure needs of low- and middle-income countries after the pandemic may alleviate this dissection, but cannot do this quickly enough. ${ }^{76}$

Pending more actual WSV's 2017-2021 findings (still to be released and assessed), one can only be speculative what comes next. For instance, the report of the United States National Intelligence Council foresees that in 2040: "International institutions focused on human development will face a more complicated operating environment as demands for their coordination efforts grow. Any increase in humanitarian and refugee crises stemming from natural and human-created causes will divert international resources from efforts to make systemic improvements in poverty and disease. The likely failure of many countries to meet the UN's 2030 Sustainable Development Goals will have the largest impact on middle-income societies where populations that have recently emerged out of poverty are demanding progress toward next levels of education [emphasis added], medical care, and environmental quality. Traditional providers of development assistance might not be able to keep up with needs. Shortfalls in multilateral development assistance could facilitate plans by China and other countries to gain advantage from financing critical urban infrastructure in developing countries".

The same report acknowledges that China with almost $20 \%$ of world's population (aging and shrinking as well) has now become a key technical assistance actor with an influence "over global norms, rules, and institutions" and with the influence on "heightening the risk of interstate conflict". ${ }^{77}$

$\mathrm{BDN} / \mathrm{B} 3 \mathrm{~W}$ and BRI are the two technical assistance programmes that for many years to come will impact the intercultural UN logic with its Culture of Lawfulness. It seeks the compromise.

${ }^{76}$ B. Kampmark, Vague Alternatives And G7 Summitry: The Build Back Better World Initiative, “Scoop World Independent News” 13 June 2021, https: / bit.ly/3r11BKN (access: 15.07.2021).

77 U.S. National Intelligence Council, A More Contested World 2040. Global Trends, Washington, D.C. 2021, https://bit.ly/3oszTCH (access: 15.07.2021). 
$340 \mid$ Stawomir Redo

\section{Conclusion}

Teaching pre-departure migrants and immigrants Rule-of-Law values in their home languages is fundamental to them, for "[a] different language is a different vision of life" (Federico Fellini). ${ }^{78}$ In emancipative legal cultures regarding others like oneself, language is a formidable force for Rule-of-Law viable outcomes because emancipative formulations can strengthen the sense of life in larger freedom, integrity and dignity.

Emancipative culture and language aside, the globally aging population implies that the systematic application of moral principles to specific problems in work and business environment will be important through the assimilation of host countries' values. ${ }^{79}$ This means - by coming closer to the beliefs of the native population as they evolve, however they may evolve, hopefully with anti-corruption in mind. Across races, sexes, religions, countries, governments, companies, work places and residential areas worldwide one common priority for advancing sustainable livelihood should be targeted: mutual regard toute proportion gardée applied locally to bolster intolerance for bribes, including to white collar criminals. ${ }^{80}$

In the above context, the following recommendations ensue:

- Since priorities and values change, in non-humanitarian technical assistance it is important to account through education, training for "reasonable" ( “fair" 无偏) mutual benefits;

- Donors should help others more than themselves. In that case, they will also benefit more. Then mutual benefits and international social justice and moral growth will be more evident and plausible;

78 B. Cardullo (ed.), Federico Fellini. Interviews, Jackson 2006, p. 178.

79 See more: H. Kury, S. Redo (eds.), Crime Prevention.

80 E.D. Jaffe, N. Kushnirovich, A. Tsimerman, The Impact of Acculturation on Immigrants' Business Ethics Attitudes, “Journal of Business Ethics" 2018, No. 147 , pp. 821-834. 
- There should be viable returns for both sides (donors/recipients). In each and every case of such non-humanitarian technical assistance a donor-recipient "equilibrium" what is "fair" ( "reasonable") in a particular legal culture will be different and never ideal "50/50";

- Non-humanitarian assistance will always be in favour of a donor. Yet locally (in-country/on-site) it should be fair and socially just, i.e. proportionate/measured to meet a local "equilibrium", according to participatory identification of local needs. This assistance should be globally morally and socially progressive, with mutual cost/benefit evaluation of outcomes in financial and Rule-of-Law terms (assessment tools: human development index, case analysis, community \& expert interviews, safety audits, household \& victimization surveys, corruption perception surveys, psychometric instruments measuring prejudice, etc.).

This is what "win-win" is about, as far as traditional interpretation of reciprocity is concerned.

Yet the United Nations' modernistic understanding of the GR is more ambitious. It involves regenerating the global commons by integrating social development with economic growth and environmental sustainability - "triple win" ${ }^{81}$ In the underlying of that concept commentary of the United Nations Secretary-General, he argued that the GR extends to the mutually satisfactory relationship between people and nature - existentially, the deepest sense of "balanced reciprocity". It "forms part of natural universal laws, and is a consistent feature in codes of conduct of indigenous communities governing their interactions with the natural world." ${ }^{82}$ It is the natural world which reacts to human conduct and reminds us who shows primordial self-preservation instinct. From "winwin" we should move to "triple wins": mutual regard in human interactions vis à vis Mother Earth.

81 United Nations Development Programme, Triple Wins for Sustainable Development, New York 2012.

82 A/70/268, Harmony with Nature. Report of the Secretary-General, $4 \mathrm{Au}-$ gust 2015, § 40 . 
Finally, in the pre-SDGs era, experts debated whether or not the Rule of Law is a "magical elixir" for all of the world's ills or a "rhetorical balloon" full of "warm air" that moves through the field as the wind blows. ${ }^{83}$ Thomas Carothers has then bluntly observed, that "rule-of-law reform will succeed only if it gets at the fundamental problem of leaders who refuse to be ruled by the law." ${ }^{4}$

In the SDGs era the following points may be relevant for the R-o-L technical assistance field:

- The Rule of Law should be popular in every legal culture like a local folk dance. The UN committed to just and fair distribution of benefits is a good conduit to stage the Rule of Law glocally as a lifelong sustainable livelihood technical cooperation strategy. Leibnitz thought that the true meaning of the GR is to judge more fairly, to adopt the point of view of other people 85 ("Platinum Rule"). Thanks to Confucius and Rawls we know that there should be reasonable limits to reciprocity. What is "due" or not is perpetually relative;

- Yet climate change alerts us to be definitely more forthcoming with reciprocity and answer appropriately to Mother Earth's self-preservation arguments. It is her who really deserves the Platinum Rule. No longer the game theory choice "take it or leave it" allows the latter option in sustainable livelihood practice. This fundamental problem leaves no choice, but to pursue the Rule of Law for the sake of peace and justice;

- As for the UN itself, its various networks of agencies, training and research institutes should be in a position to bridge U.S.', China's and EU's comparative advantages. The 2030 Sustainable Development Agenda is an extremely suitable avenue to balance mutual benefits for infrastructure providers and recipients in terms of common corruption challenge for a truly better world. The UN may win the hearts and minds of people with the sight and sound of audacious fu-

83 Quoted after: S. Chalmers, The Mythology, p. 958.

84 T. Carothers, The Rule of Law Revival, "Foreign Affairs" 1998, Vol. 77(2), p. 96.

85 G.W. Leibnitz, New Essays (1997), Book I, § 4, 92. 
ture in harmony with nature as we move on, mindful that peace and justice is at stake;

- Our business should not be to make people read, but to have more Rule-of-Law "win-win" outcomes in a "spirit of brotherhood". These UN terms first appeared in the Universal Declaration of Human Rights which invoked the GR. Given the respective West-East origin of both terms, would it now make sense to re-emphasize that they may be compatible with one another when it comes to B3W/BDN and RBI? After all, a truly better world means leveraging all parties' comparative advantages, ensuring sustainability and high environmental standards, promoting development and prosperity at a global scale, and bringing mutual benefits for infrastructure providers and recipients ${ }^{86}$;

- The way to demonstrate the systemic connections between one and the other megaproject is to include in both of them participatory measures determining people's Rule-of-Law needs. This may be a thin blue line for the start. It should thicken and produce genuinely beneficial Rule-of- Law "winwin" outcomes.

Alexander the Great and the pirate would have been bewildered to see how hopefully dominant the Rule of Law may become across the high seas and foreign lands. Under one condition, though: if and when their rulers realize that sooner or later refusing the Ruleof-Law serves our own self-detriment.

\section{SUMMARY}

For more United Nations rule-of-law "win-win" technical assistance outcomes amid migration

This article focuses on the universal and time-honored Golden Rule, colloquially known as "win-win"- a technical cooperation strategy, pursued in

${ }^{86}$ K. Zhou, 'Build Back Better World' and the Belt and Road Are Not Necessarily at Odds, "The Diplomat", 28 June 2021, https://bit.ly/3hPhEVO (access: 15.07.2021). 
crime prevention and other fields. In particular, the article ventures into John Rawls's difference principle for the United Nations-inspired Ruleof-Law cooperation for crime prevention to meet sustainable development goal 10 of the 2030 United Nations Agenda ("Reduce inequality within and among countries"). His liberally egalitarian principle regards inequality as reasonable (justice as fairness) as long as it would make the least advantaged in society materially better off than they would be under strict equality. In line with the United Nations Charter establishing the duty to cooperate, the author looks into the principle's Global North-South applicability, relevant especially for the Rule-of-Law impact on the benefactors and beneficiaries of the two major economic development initiatives: the 2019-2021 Blue Dot Network/Build Back Better World (BDN/B3W) and the 2013 Belt and Road Initiative (BRI), both prone to migration flows. In their context he offers intercultural rationale and suggestions for a NorthSouth crime prevention technical cooperation glocal ${ }^{87}$ approach that should be programmatically driven by universally relevant anticorruption. Finally, the author alerts to the need of bringing into the North-South technical cooperation relationship people's regard of Mother Earth ("triple wins") and strategize that cooperation accordingly for a truly better world.

Keywords: crime prevention; difference principle; Golden Rule; justice; fairness; migration; mutual benefits; reciprocity; Rule of Law; sustainable development; technical assistance; United Nations; win-win

\section{STRESZCZENIE}

\section{Rządy prawa ONZ - o więcej korzystnie zrównoważonych wyników pomocy technicznej pomimo migracji}

Przedmiotem artykułu jest uniwersalna i uhonorowana czasem złota reguła, potocznie znana jako sytuacja, w której są tylko wygrani, w tym wypadku dzięki strategii pomocy technicznej realizowanej $\mathrm{w}$ zapobieganiu przestępczości i na innych polach. W szczególności niniejszy tekst wgłę-bia się $\mathrm{w}$ zasadę zróżnicowania Johna Rawlsa odniesioną do profilaktyki przestępczości drogą rządów prawa inspirowanych przez Organizację Narodów Zjednoczonych w celu osiągnięcia celu 10 jej Agendy na rzecz zrównoważonego rozwoju do 2030 r. (,Zmniejszyć nierówności w krajach i między krajami”). Jego

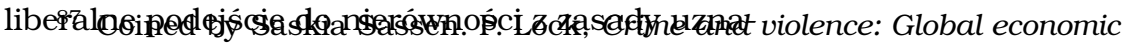
parameters, 2006, https://bit.ly/3jJKBnW (access: 15.07.2021). 
je ją za rozsądną, tj. sprawiedliwą (just) i słuszną (fair), o ile najbardziej tą nierównością materialną upośledzeni skorzystają $z$ tej zasady na tyle, że będą w lepszej sytuacji, niż gdyby panowała absolutna równość. W zgodzie z Kartą Narodów Zjednoczonych obligującą państwa do współpracy autor stosuje tę zasadę w stosunkach Północ - Południe, zwłaszcza jeśli chodzi o korzyści wynikające $z$ rządów prawa dla partnerów pomocy technicznej w ramach dwóch megaprojektów: Sieci Błękitnej Kropki/Odbudowania Lepszego Świata 2019-2021 oraz Inicjatywy Błękitnego Pasa i Szlaku z 2013 r., obydwu podatnych na przepływy migracyjne. W ich kontekście autor przedstawia międzykulturowo drożną racjonalizację współpracy technicznej Północ - Południe w zakresie prewencji przestępczości globalnie i lokalnie. Pragmatyczne przeciwdziałanie korupcji powinno być głównym celem tej części profilaktyki kryminalnej. W końcu autor podnosi potrzebę szerszego uwzględnienia we współpracy technicznej Północ - Południe wzajemności. Jej większe i konkretniejsze, praktyczne uwzględnienie, zorientowane na ochronę środowiska naturalnego na poziomie lokalnych społeczności objętych pomocą techniczną, wpłynie na poprawę relacji człowieka $z$ Matką Ziemią (triple wins). To jest najbardziej aktualny paradygmat Agendy 2030 dla budowania rzeczywiście lepszego świata.

Słowa kluczowe: zapobieganie przestępczości; zasada zróżnicowania; złota reguła; sprawiedliwość; słuszność; migracja; wzajemne korzyści; wzajemność; zrównoważony rozwój; pomoc techniczna; Narody Zjednoczone; "win-win"

\section{BIBLIOGRAPHY}

$\mathrm{A} / \mathrm{HRC} / 43 / 31$, The role of technical assistance and capacity-building in fostering mutually beneficial cooperation in promoting and protecting human rights, 17 January 2020.

A/RES/55/2, The Millennium Goals Declaration, 18 September 2000.

A/RES/70/1, Transforming Our World: the 2030 Agenda for Sustainable Development, 25 September 2015.

A/70/268, Harmony with Nature. Report of the Secretary-General, 4 August 2015.

A/RES/73/195, The Global Compact for Safe, Orderly and Regular Migration, 19 December 2018.

Analects. The Chinese Classics: Translated into English with Preliminary Essays and Explanatory Notes by James Legge, Vol. 1: The Life and Teachings of Confucius, $2^{\text {nd }}$ ed., London 1869. 
Aristotle, in: The Basic Works of Aristotle, ed. R. McKeon, New York 2001.

Baker B., Scheye E., Access to Justice in a Post-conflict State: Donor-supported Multidimensional Peacekeeping in Southern Sudan, "International Peacekeeping” 2009, Vol. 16(2), pp. 171-185.

Bień-Kacała A., Drinóczi T., Rule of Law, Common Values, and Illiberal Constitutionalism Poland and Hungary within the European Union, London 2021.

Boyd R., Richerson P., Group Beneficial Norms Can Spread Rapidly in a Structured Population, "Journal of Theoretical Biology" 2002, Vol. 215(3), pp. 287-296.

Cardullo B. (ed.), Federico Fellini. Interviews, Jackson 2006.

Carothers T., The Rule of Law Revival, "Foreign Affairs" 1998, Vol. 77(2), pp. 95-106.

Cerqueti R., Coppier R., A game theoretical analysis of the impact of income inequality and ethnic diversity on fiscal corruption, "Annals of Operations Research” 2016, No. 243, pp. 71-87, doi: 10.1007/s10479-0141567-9.

Chalmers S., The Mythology of International Rule-Of-Law Promotion, "Law and Social Inquiry” 2012, Vol. 44(4), pp. 957-986.

Cholwerinski R., Can Artificial Intelligence lessen biases and create a "veil" in businesses? (2018), https://bit.ly/3qMHg96.

Confucius, The Analects of Confucius. A Philosophical Translation, transl. R.T. Ames, H. Rosemont Jr, New York 1998.

Congressional Record. United States of America. Proceedings and Debates of the $114^{\text {th }}$ Congress, First Session, Vol. 161, Washington, September 24, 2015, No. 138, https://bit.ly/3yhFgIG.

Dawson M.M., The Ethics of Confucius. The Sayings of the Master and his Disciples upon the Conduct of "The Superior Man", Arranged According to the Plan of Confucius with Running Commentary, New York 1915.

Doxbury N., Golden Rule Reasoning, Moral Judgment, and Law, "Notre Dame Law Review” 2009, Vol. 74, p. 1591-1606.

Duff A.S., Neo-Rawlsian Co-ordinates: Notes on A Theory of Justice for the Information Age, "International Review of Information Ethics" 2006, Vol. 6(12), pp. 18-21.

Eikema Hommes H. van, Grotius on Natural and International Law, "Netherlands International Law Review” 1983, Vol. 30(1), pp. 61-71.

Extreme Poverty - Data Documentation, https://bit.ly/2UsGUZt.

Germantown Friends' protest against slavery 1688 [Facsimile], https:// bit.ly/3hePKmr. 
Hatch J., 6 Ways Artificial Intelligence is Being Used in International Development, 8 August 2019, https://bit.ly/3fF5BbO.

Henrich J. et al., Costly Punishment Across Human Societies, "Science" 2006, Vol. 312, pp. 1767-1770.

Henrich J., Boyd R., Why People Punish Defectors: Weak Conformist Transmission can Stabilize Costly Enforcement of Norms in Cooperative Dilemmas, “Journal of Theoretical Biology" 2001, Vol. 208(1), pp. 79-89.

Inglehart-Welzel Cultural Map, https://bit.ly/3qSKNTE.

Jaffe E.D., Kushnirovich N., Tsimerman A., The Impact of Acculturation on Immigrants' Business Ethics Attitudes, “Journal of Business Ethics” 2018, No. 147, pp. 821-834.

Kampmark B., Vague Alternatives and G7 Summitry: The Build Back Better World Initiative, 13 June 2021, “Scoop World Independent News”, https://bit.ly/3r11BKN.

Kury H., Redo S., Prologue, in: Crime Prevention and Justice in 2030. UN and the Universal Declaration of Human Rights, eds. H. Kury and S. Redo, Cham 2021.

Kury H., Redo S. (eds.), Refugees and Migrants in Law and Policy - Challenges and Opportunities for Global Civic Education, Cham 2018.

Leibnitz G.W., New Essays on Human Understanding, eds. and transl. P. Remnant, J. Bennett, Cambridge 1997.

Leibnitz G.W., New Essays on Human Understanding ed. and transl. J. Bennett, https://bit.ly/3AvsZSL.

Lock P., Crime and violence: Global economic parameters, 2006, https:// bit.ly/3jJKBnW.

Machiavelli N., History of Florence, in: The Collected Works of Niccolò Machiavelli: The Complete Works, PergamonMedia 2015.

Montesquieu Ch., Persian Letters, transl. R.N. Mackenzie, Indianapolis/ Cambridge 2014.

Montesquieu Ch., The Spirit of Laws, transl. T. Nugent, Kitchener, ON 2001.

Oyvind E., Kjell R., Western Aid at a Crossroads. Western Aid at a Crossroads: The End of Paternalism, London 2014.

Pufendorf S., On the Law of Nature and Nations, $4^{\text {th }}$ ed., London 1729.

Rawls J., Justice as Fairness. Political not Methaphysical, "Philosophy \& Public Affairs” 1985, Vol. 14(3), pp. 223-251.

Rawls J., A Theory of Justice, Cambridge 1971.

Redo S., Blue Criminology. The Power of the United Nations Ideas to Counter Crime Globally, Helsinki 2012. 
Redo S., The Relevance of Philosophical and Religious Ideas to the United Nations Quest for Universalizing Criminal Justice, in: Crime Prevention and Justice in 2030. UN and the Universal Declaration of Human Rights, eds. H. Kury, S. Redo, Cham 2021.

Roetz H., Transfer in Dispute: The Case of China, in: Cultural Transfers in Dispute Representations in Asia, Europe and the Arab World since the Middle Ages, eds. J. Feuchter, F. Hoffmann, B. Yun, Frankfurt-New York 2011, pp. 279-280.

Rono J.K., The Golden Rule as an Alternative Approach in the Fight Against Corruption, "Research on Humanities and Social Sciences" 2017, Vol. 7(16), pp. 1-10.

Roser M., Ortiz-Ospina E., Global Extreme Poverty, https://bit.ly/3jZOPcS. Saint-Exupéry A. de, "The Wisdom of the Sands", in: La Citadel, transl. S. Gilbert, New York 1948.

Seok B., Justice and Religion: Confucianism, in: Encyclopedia of Global Justice 2011, https://doi.org/10.1007/978-1-4020-9160-5_145.

Sharp M., Canada's Stake in International Programmes, “Dialogue” 1961, pp. 45-51.

Simma B. (ed.), Paulus A., Chatodou E. (ass. eds.), in collaboration with Mosler M., Radelzhofer A., Tomuschat Ch. and Wolfrum R., The Charter of the United Nations. A Commentary, Oxford 2002.

Singer M., “Golden Rule”, in: Encyclopedia of Philosophy, ed. D.M. Borchert, $2^{\text {nd }}$ ed., Detroit, MI 2006, https://bit.ly/36smWRm.

St. Augustine, Concerning the City of God against the Pagans, transl. H. Bettenson, London 1972.

St. Augustine, Sermon on the Mount; Harmony of the Gospels; Homilies on the Gospels, in: P. Schaff, Nicene and Post-Nicene Father Series, Christian Classics Ethereal Library 2010.

U.S. National Intelligence Council, A More Contested World 2040. Global Trends, Washington, D.C. 2021, https://bit.ly/3oszTCH.

United Nations Development Programme, Triple Wins for Sustainable Development, New York 2012.

Universal Declaration of Human Rights, General Assembly resolution 2017 (III A), 10 December 1948.

Vogel G., The Evolution of the Golden Rule, "Science" 2004, Issue 303, pp. 1128-1131, doi: 10.1126/science.303.5661.1128.

Volk Ch., The Law of the Nations and the Civil Law of the World. On Montesquieu's political Cosmopolitanism, in: Order, and International Law System. The Early History of International Legal Thought from Machiavel- 
li to Hegel, eds. S. Kadelbach, T. Kleinlein, and D. Roth-Isigkeit, Oxford 2017, pp. 241-259.

WHO Director-General's opening remarks at $148^{\text {th }}$ session of the Executive Board, 18 January 2021, https://bit.ly/3jNCVkM.

Yu A.C., Comparative Journeys: Essays on Literature and Religion East and West, New York 2009.

Zhang Y.-J., The Universal Declaration of Human Rights: Public International Law and the Confucian Legal Culture for 2030 and Beyond, in: Crime Prevention and Justice in 2030. UN and the Universal Declaration of Human Rights, eds. H. Kury, S. Redo, Cham 2021.

Zhou K., 'Build Back Better World' and the Belt and Road Are Not Necessarily at Odds, “The Diplomat”, 28 June 2021, https://bit.ly/3hPhEVO. 
